\title{
ANALISIS HISTOPATOLOGIS INSANG DAN KANDUNGAN LOGAM BERAT PB, CD DAN FE PADA IKAN NILA (OREOCHROMIS NILOTICUS) YANG DIBUDIDAYAKAN DI KOLAM BEKAS TAMBANG KOTA SAMARINDA
}

\author{
Sudrajat $^{1^{*}}$, Dwi Astuti ${ }^{2}$, Muhamad Mustakim $^{3}$ \\ ${ }^{1}$ Dosen Program Magister Ilmu Lingkungan, Sekolah Pascasarjana Unmul. \\ ${ }^{2}$ Dinas Perikanan dan Kelautan Provinsi Kalimantan Timur \\ ${ }^{3}$ Dosen Fakultas Perikanan dan Ilmu Kelautan Unmul \\ Koresponden E-mail: sudrajat.fmipa@gmail.com
}

\begin{abstract}
Coal mining activities openly cause the formation of mine pits and are currently used by the community for fish farming. This research aims to determine the histopathological status of gills, heavy metal content $(\mathrm{Pb}, \mathrm{Cd}$, and $\mathrm{Fe})$ in tilapia fish (Oreochromis niloticus) and water bodies ponds. Samples were taken by purposive sampling technique at four locations with different ages, namely Senong Pit (5 years), Goldstar Pit (10 years), Bendang Galactic Pit (15 years) and Control. Measuring heavy metal content was carried out using AAS. Fish gills are processed by the paraffin method and hematoxylin-eosin staining. The results of the analysis of the heavy metal content of $\mathrm{Pb}, \mathrm{Cd}$, and $\mathrm{Fe}$ in surface water in all ponds are below the Class II Water quality standard based on the Provincial Regulation of East Kalimantan No. 02 of 2011. The value of heavy metal concentrations in sediments is higher than in water. Pb content in Tilapia (Oreochromis niloticus) meat from all ponds is between 2.92 to $4.41 \mathrm{mg} / \mathrm{kg}$, while Cd is between 0.02 to $0.03 \mathrm{mg} / \mathrm{kg}$. The $\mathrm{Pb}$ metal content status of the results of this study is above the limit of heavy metal contamination determined by BPOM Decree No. 5 of 2018 which is $0.02 \mathrm{mg} / \mathrm{kg}$, while the heavy metal Cd is still below the specified limit of $0.10 \mathrm{mg}$ $/ \mathrm{kg}$. The total content of Fe metal ions in fish meat is $83.64 \mathrm{up}$ to $144.92 \mathrm{mg} / \mathrm{kg} \mathrm{bw}$ These results indicate the total content of Fe ions is far above the safe limit standard for the presence of Fe contaminants in all food sources based on FAO / WHO (2011) of $0.8 \mathrm{mg} / \mathrm{kg}$. Fish originating from all post-mining pond ages indicate damage to the histological structure gills which are characterized by damage to epithelial cells, changes in secondary lamella structures characterized by hyperplasia, destruction of secondary lamella structures and filaments, lamella aneurism and secondary lamella fusion. The results showed that histopathologically and bioaccumulation of heavy metals in fish meat from postmining ponds showed unhealthy conditions.
\end{abstract}

\section{Keywords: Histopathological Gills, Heavy Metals, Post-Mining Coal Ponds}

Kalimantan Timur memiliki sumber daya alam yang melimpah, salah satunya adalah batubara. Kegiatan penambangan batubara di kawasan ini menggunakan sistem penambangan terbuka (open pit mining), dimana sistem ini menyebabkan terbentuknya lubang tambang. Pada tahun 2017 terdapat sekitar 264 lubang tambang batubara yang tersebar di beberapa kabupaten dan kota di Provinsi Kalimantan Timur. Lubang-lubang bekas tambang batubara yang tidak ditimbun kembali telah banyak dimanfaatkan oleh masyarakat untuk usaha budidaya ikan dengan menggunakan keramba. Salah satu jenis ikan yang dibudidayakan adalah ikan Nila (Oreochromis niloticus).

Dalam kegiatan pemanfaatan kolam pasca tambang batubara tersebut, masyarakat dihadapkan terhadap adanya kandungan logam berat $\mathrm{Fe}, \mathrm{Al}, \mathrm{Pb}$, $\mathrm{Zu}, \mathrm{Cd}$ dan $\mathrm{Zn}$ yang tinggi di air dan sedimen (Wahyuni dkk., 2013).Logam berat menimbulkan risiko serius bagi lingkungan akuatik karena toksisitas, akumulasi, dan pertumbuhannya (Roy 2010).Sebagian besar dari logam logam tersebut $(\mathrm{Zn}, \mathrm{Cu}, \mathrm{Ni}, \mathrm{Cr}, \mathrm{Pb}$, $\mathrm{Cd}, \mathrm{Hg}$, dll.) digolongkan sebagai zat berbahaya di banyak negara karena sifat toksisitas, persistensi, dan bioakumulasinya. Logam berat terakumulasi dalam insang, hati, ginjal, dan otot ikan,melalui ikatan kuat dengan metallothioneins atau protein pengikat logam lainnya.Kation logam berat diakumulasi di dalam sel akan memacu sintesis metalloproteinneosynthesis melalui proses transkrisi gen metallothioneins (E1Sikaily et al,2016, Sorensen 1991; Valavanidis et al. 2006).

Logam berat, seperti merkuri, kadmium, tembaga, timah dan seng adalah polutan terpenting yang mempengaruhi lingkungan perairan dan ikan.Sebagian besar logam ini ditandai dengan terakumulasi dalam jaringan, dan menyebabkan keracunan ikan. Logam-logam ini dapat secara efektif mempengaruhi proses metabolisme utama dan reproduksi ikan; melemahkan sistem kekebalan tubuh, dan menyebabkan perubahan patologis(Authman et al,2015).

Dalam ekosistem perairan, ikan dianggap sebagai indikator berharga dalam pencemaran lingkungan karena berada di puncak rantai makanan akuatik dan diketahui menumpuk racun (Authman et al., 2012). Insang ikan adalah organ target pertama dari beberapa xenobiotik karena kontak langsung dengan air (Perry dan Laurent, 1993). Histopatologi insang dapat digunakan sebagai biomarker dalam kegiatan penilaian kualitas air dan tingkat pencemaran lingkungan (Wood,2001).

.Logam berat terlarut dalam badan perairan pada kosentrasi tertentu akan menjadi sumber racun bagi organisme di perairan. Pencemaran logam berat diduga dapat memicu kerusakan secara struktural dan fungsional pada berbagai organ ikan. Salah satu organ yang sensitif terhadap pencemaran adalah insang. 
Saat ini informasi tentang kerusakan mikroanatomi insang dan akumulasi logam berat pada daging ikan nila yang dipelihara pada kolam pasca tambang batubara yang berbeda umurnya masih sedikit.Adanya perbedaan kondisi lingkungan kolam pasca tambang yang berbeda umurnya diduga dapat menyebabkan perbedaan histopatologi insang dan kandungan logam berat dalam dagingnya Penelitian ini bertujuan menganalisis struktur jaringan insang ikan dan kandungan logam berat $(\mathrm{Pb}, \mathrm{Cd}$ dan $\mathrm{Fe})$ dalam daging ikan Nila (Oreochromis niloticus) yang berasal dari kegiatan budidaya di kolam pasca tambang batubara..

\section{BAHAN DAN METODE}

Ikan contoh ditangkap dari tiga lokasi kolam pasca tambang yakni kolam pasca tambang Pit 1 Senong, kolam Pit 2 Goldstar dan kolam Pit 3 Galaxy Bendang( Lihat Gambar 1).Bahan-bahan yang digunakan dalam penelitian adalah sampel ikan nila , akuades, dan beberapa bahan kimia yang mencakup asam nitrat ( $\mathrm{HNO} 3)$, asam perklorat ( $\mathrm{HClO} 4)$ (Merck), larutan fikasif, methanol, ethanol, toluol, xylol, HE staining, standar logam $\mathrm{Fe}, \mathrm{Pb}$ dan $\mathrm{Cd}$. Preparasi dan Analisa Timbal $(\mathrm{Pb})$ dan Cadmium (Cd) pada sampel Ikan Nila mengikuti prosedur SNI 2354.5:2011.Alat yang digunakan adalah jaring insang, alat bedah, labu ukur $50 \mathrm{ml}$ (Pyrex), oven (Memmert), kertas saring, hot plate, desikator, erlenmeyer (Iwaki Pyrex), pipet volumetrik (Pyrex), bulb, mortar, cawan petri, staining jar,mikrofograf, dan Atomic Absorbtion Spectrophotometer (AAS) (Shimadzu AA 7000).

\section{Bahan dan Alat}

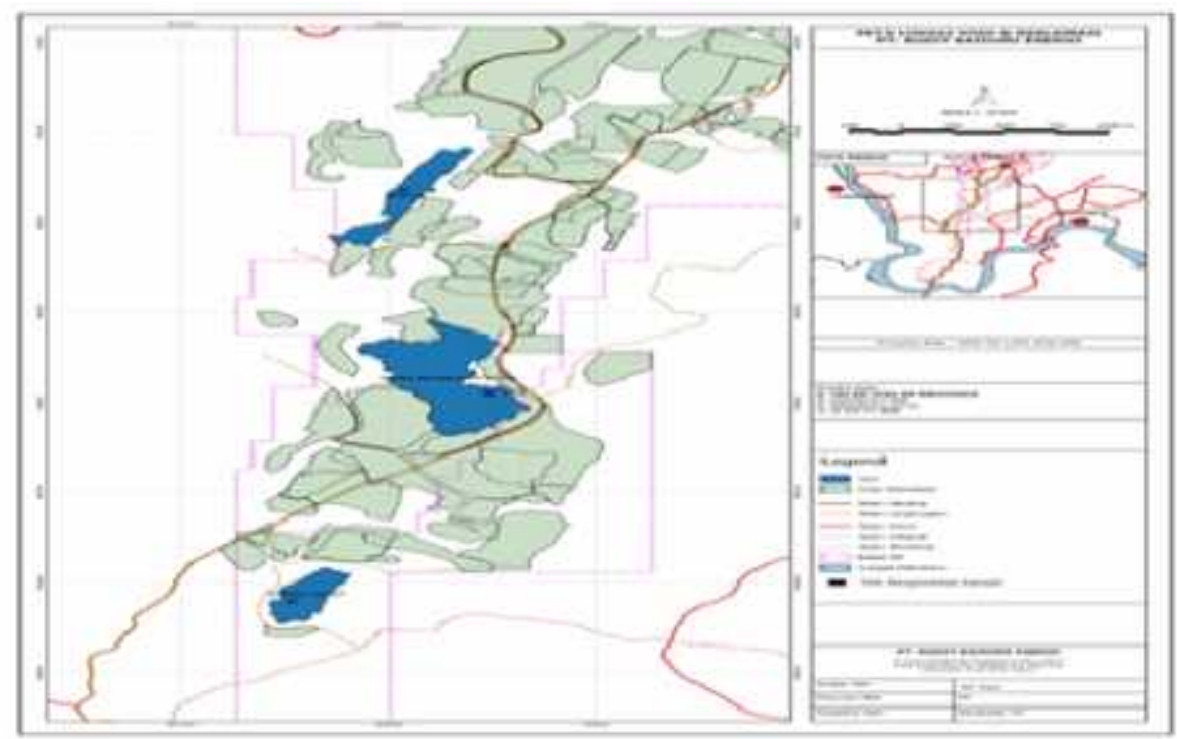

Gambar 1. Lokasi Penelitian

\section{Keterangan;}

1. Kolam Pasca Tambang Pit 1 Senong (umur 5 tahun)

2. Kolam Pasca Tambang Pit 2 Goldstar (umur 10 tahun)

3. Kolam Pasca Tambang Pit 3 Galaxy Bendang(umur 15 tahun)

\section{Analisis histologis insang ikan}

Pengambilan sampel ikan Nila (Oreochromis niloticus ) (masing masing sepuluh ekor ikan dari setiap lokasi ) menggunakan jala. Sampel kemudian diukur panjang tubuhnya. Panjang ikan yang digunakan dalam penelitian ini berkisar antara 15$17 \mathrm{~cm}$. Selanjutnya ikan dibedah untuk mengambil insangnya di bagian sisi kanan. Insang diamati morfologinya, kemudian dicuci dengan larutan garam fisiologis yang bertujuan untuk membuang darah, sisa cairan jaringan dan lemak yang menempel, lalu difiksasi dengan menggunakan larutan Bouin's selama 8 jam dan dibawa ke laboratorium.

Pembuatan preparat histologis diawali dengan proses dehidrasi sampel dalam alkohol secara bertingkat dimulai dari konsentrasi $50 \%$ hingga konsentrasi $100 \%$ yang disusul dengan penjernihan menggunakan xilol, kemudian insang tersebut ditanam dalam parafin. Insang yang telah ditanam, kemudian disayat dan ditempel pada kaca objek yang telah dilapisi dengan Meyer's albumin. Sayatan yang telah ditempel kemudian diparafinisasi dengan menggunakan xilol lalu diwarnai dengan Haematoxylin-Eosin (Suntoro, 1983). Pengamatan terhadap preparat yang diamati terdiri atas jenis kerusakan sel pada jaringan insang.

\section{Analisis Kandungan Logam Berat $\mathrm{Pb}, \mathrm{Cd}$ dan $\mathrm{Fe}$ di Perairan dan Daging Ikan}

Analisis logam berat digunakan daging ikan yang diambil pada bagian lateral/samping (di atas garis sisi- 
lateral line, di bawah sirip dorsal) sebanyak 30-50 gram (dari gabungan sampel) yang dilakukan per lokasi pengamatan. Analisis logam berat $\mathrm{Pb}, \mathrm{Cd}$ dan $\mathrm{Fe}$ pada ikan dilakukan dengan menggunakan metode AAS.

\section{HASIL}

\section{Logam Berat di badan perairan dan ikan}

Hasil analisis kandungan ion logam berat $\mathrm{Pb}$, $\mathrm{Cd}$ dan $\mathrm{Fe}$ pada badan air dan daging Ikan Nila yang berasal dari kegiatan budidaya di kolam pasca tambang disajikan pada Tabel 1.dan Tabel 2

Tabel 1. Kandungan Ion Logam Berat $\mathrm{Pb}, \mathrm{Cd}$ dan $\mathrm{Fe}$ dalam daging Ikan Nila yang Dibudidayakan di Kolam Pasca Tambang

\begin{tabular}{|c|c|c|c|c|c|}
\hline $\begin{array}{c}\text { Ion Logam } \\
\text { Berat } \\
(\mathrm{mg} / \mathrm{Kg})\end{array}$ & Ulangan & $\begin{array}{c}\text { Pit Senong } \\
\text { (5 tahun) }\end{array}$ & $\begin{array}{c}\text { Pit Goldstar } \\
\text { (10 tahun) }\end{array}$ & $\begin{array}{c}\text { Pit GB } 657 \\
\text { (15 tahun) }\end{array}$ & $\begin{array}{c}\text { Baku Mutu } \\
\text { (mg/Kg) }\end{array}$ \\
\hline $\mathbf{P b}$ & 1 & 4,85 & 6,42 & 4,51 & $0,3^{\mathrm{a})}$ \\
\hline & $\begin{array}{c}2 \\
3 \\
\text { Rata-rata }\end{array}$ & $\begin{array}{l}2,48 \\
1,42 \\
2,92\end{array}$ & $\begin{array}{l}5,52 \\
4,28 \\
\mathbf{5 , 4 1}\end{array}$ & $\begin{array}{l}2,26 \\
3,27 \\
3,25\end{array}$ & \\
\hline Cd & $\begin{array}{l}1 \\
2 \\
3\end{array}$ & $\begin{array}{l}0,03 \\
0,02 \\
0,01\end{array}$ & $\begin{array}{l}0,05 \\
0,01 \\
0,02\end{array}$ & $\begin{array}{l}0,04 \\
0,01 \\
0,02\end{array}$ & $0,1^{\text {a) }}$ \\
\hline $\mathrm{Fe}$ & $\begin{array}{c}\text { Rata-rata } \\
1 \\
2 \\
3 \\
\text { Rata-rata }\end{array}$ & $\begin{array}{c}\mathbf{0 , 0 2} \\
117,18 \\
71,92 \\
61,83 \\
83,64\end{array}$ & $\begin{array}{c}\mathbf{0 , 0 3} \\
77,72 \\
166,64 \\
186,64 \\
143,67\end{array}$ & $\begin{array}{c}\mathbf{0 , 0 2} \\
86,12 \\
238,46 \\
110,19 \\
144,92\end{array}$ & $100^{b)}$ \\
\hline
\end{tabular}

Keterangan :

a). Peraturan BPOM No 5 tahun 2018 tentang batas cemaran logam berat dalam ikan dan produk perikanan

b). FA0/WHO (2011)

Tabel 2. Kandungan Ion Logam Berat pada Air dan Sedimen di Kolam Pasca Tambang

\begin{tabular}{|c|c|c|c|c|c|c|c|}
\hline \multirow[t]{2}{*}{$\begin{array}{l}\text { Lokasi } \\
\text { Kolam }\end{array}$} & \multirow[t]{2}{*}{$\begin{array}{c}\text { Titik Koordinat } \\
\text { Lokasi }\end{array}$} & \multicolumn{2}{|c|}{ Ion $\mathbf{P b}^{2+}$} & \multicolumn{2}{|c|}{ Ion $\mathbf{C d}^{2+}$} & \multicolumn{2}{|c|}{ Total Ion Fe } \\
\hline & & $\begin{array}{c}\text { Air } \\
(\mathrm{mg} / \mathrm{L})\end{array}$ & $\begin{array}{l}\text { Sedimen } \\
(\mathrm{mg} / \mathrm{Kg})\end{array}$ & $\begin{array}{c}\text { Air } \\
(\mathrm{mg} / \mathrm{L})\end{array}$ & $\begin{array}{l}\text { Sedimen } \\
(\mathrm{mg} / \mathrm{Kg})\end{array}$ & $\underset{(\mathrm{mg} / \mathrm{L})}{\operatorname{Air}}$ & $\begin{array}{l}\text { Sedimen } \\
(\mathrm{mg} / \mathrm{Kg})\end{array}$ \\
\hline Pit & S $00^{\circ} 26^{\prime} 23.07^{\prime \prime}$ & $<0,003$ & 6,92 & $<0,002$ & 0,15 & $<0,003$ & 245,58 \\
\hline Senong & E 11704'17.70” & & & & & & \\
\hline (5 thn) & $\begin{array}{l}\text { S } 00^{\circ} 26^{\prime} 23.08^{\prime \prime} \\
\text { E } 117^{\circ} 04^{\prime} 17.40^{\prime \prime}\end{array}$ & $<0,003$ & 6,92 & $<0,002$ & 0,14 & $<0,003$ & 244,71 \\
\hline & $\begin{array}{l}\text { S } 00^{\circ} 26^{\prime} 23.11^{\prime \prime} \\
\text { E } 117^{\circ} 04^{\prime} 17.12^{\prime \prime}\end{array}$ & $<0,003$ & 7,08 & $<0,002$ & 0,10 & $<0,003$ & 244,49 \\
\hline & Rata-rata & $<0,003$ & 6,97 & $<0,002$ & 0,13 & $<0,003$ & 244,93 \\
\hline \multirow{4}{*}{$\begin{array}{l}\text { Pit } \\
\text { Goldstar } \\
\text { (10 thn) }\end{array}$} & $\begin{array}{l}\text { S 00²9'28.22" } \\
\text { E } 117^{\circ} 04^{\prime} 06.54^{\prime \prime}\end{array}$ & $<0,003$ & 0,97 & $<0,002$ & 0,10 & $<0,003$ & 226,48 \\
\hline & $\begin{array}{l}\text { S 00²9'28.53" } \\
\text { E } 117^{\circ} 04^{\prime} 07.18^{\prime \prime}\end{array}$ & $<0,003$ & 9,17 & $<0,002$ & 0,20 & $<0,003$ & 246,76 \\
\hline & $\begin{array}{l}\text { S } 00^{\circ} 29^{\prime} 28.42^{\prime \prime} \\
\text { E } 117^{\circ} 04^{\prime} 07.55^{\prime \prime}\end{array}$ & $<0,003$ & 10,62 & $<0,002$ & 0,20 & $<0,003$ & 246,51 \\
\hline & Rata-rata & $<0,003$ & 6,92 & $<0,002$ & 0,17 & $<0,003$ & 239,92 \\
\hline $\begin{array}{l}\text { Pit GB } \\
657\end{array}$ & $\begin{array}{l}\text { S } 00^{\circ} 26^{\prime} 23.07^{\prime \prime} \\
\text { E } 117^{\circ} 04^{\prime} 17.70^{\prime \prime}\end{array}$ & $<0,003$ & 7,56 & $<0,002$ & 0,12 & $<0,003$ & 243,91 \\
\hline \multirow[t]{2}{*}{$(15$ thn $)$} & $\begin{array}{l}\text { S } 00^{\circ} 26^{\prime} 23.07^{\prime \prime} \\
\text { E } 117^{\circ} 04^{\prime} 17.70^{\prime \prime}\end{array}$ & $<0,003$ & 6,76 & $<0,002$ & 0,13 & $<0,003$ & 241,65 \\
\hline & $\begin{array}{l}\text { S } 00^{\circ} 26^{\prime} 23.07^{\prime \prime} \\
\text { E } 117^{\circ} 04^{\prime} 17.70^{\prime \prime}\end{array}$ & $<0,003$ & 10,30 & $<0,002$ & 0,14 & $<0,003$ & 242,28 \\
\hline $\begin{array}{l}\text { Baku } \\
\text { Mutu }\end{array}$ & Rata-rata & $\begin{array}{c}<\mathbf{0 , 0 0 3} \\
0,03^{\text {a) }}\end{array}$ & $\begin{array}{c}\mathbf{8 , 2 1} \\
50-220^{\mathrm{b})}\end{array}$ & $\begin{array}{c}<\mathbf{0 , 0 0 2} \\
0,01^{\mathrm{a})}\end{array}$ & $\begin{array}{c}\mathbf{0 , 1 3} \\
1,5-10^{\mathrm{b})}\end{array}$ & $\underset{5^{\mathrm{a})}}{<0,003}$ & $\begin{array}{l}242,61 \\
20^{c)}\end{array}$ \\
\hline
\end{tabular}

Keterangan :

a). Baku mutu Perda Provinsi Kaltim No.02 Thn 2011.

b). Recommended Sediment Quality Guidelines ANZECC / ARMCANZ 2000

c). Baku mutu sedimen dengan standard sediment quality guideline values for metals and associated levels of concern to be used in Doing assesments of sediment quality (2003) 
Hasil analisis mikrofotograf disajikan dalam Gambar 2 s.d. 5.

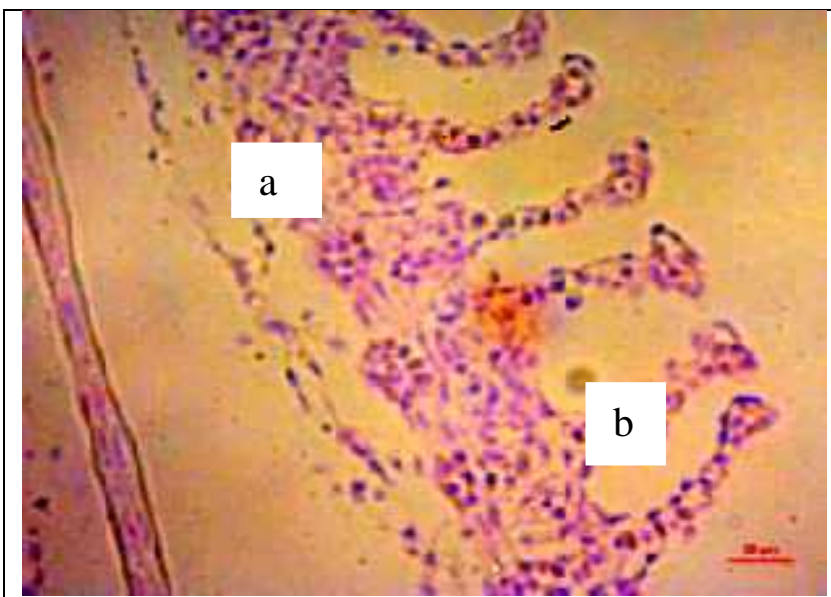

Gambar 2. Mikrofotograf penampang membujur lamella primer(a) dan lamella sekunder(b) ikan nila O.niloticus kontrol.HE x 400

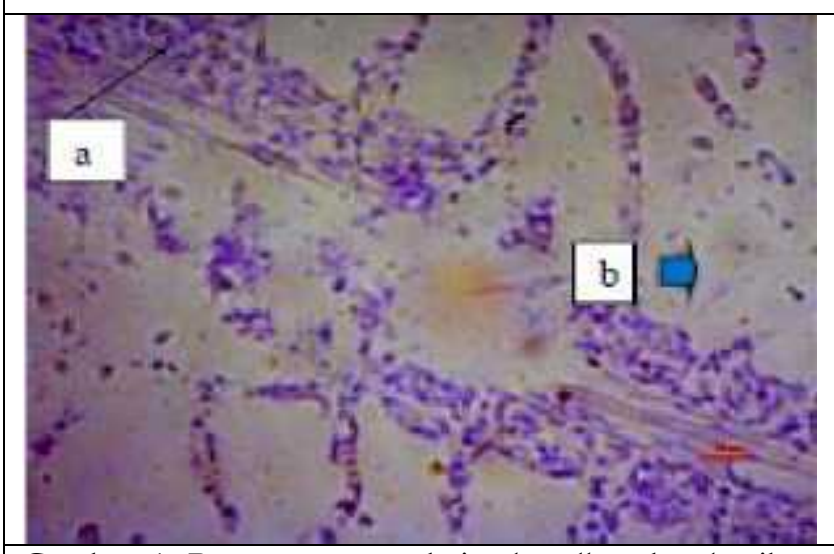

Gambar 4. Penampang membujur lamella sekunder ikan nila dari kolam bekas Pit Goldstar (umur 10 tahun). Terlihat sel-sel epitelium filamen mengalami proliferasi(a) dan struktur lamella sekunder mengalami penghancuran ( b).HE X 400

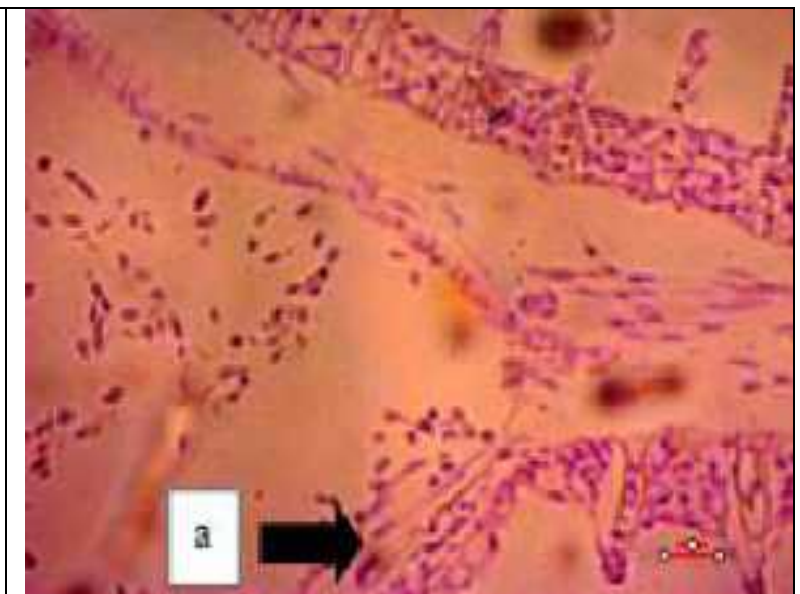

Gambar 3.Mikrofotograf penampang membujur lamella sekunder ikan nila dari kolam bekas Pit Senong (umur 5 tahun). Terlihat struktur lamella sekunder mengalami hiperplasi ( keterangan a). HE X 400

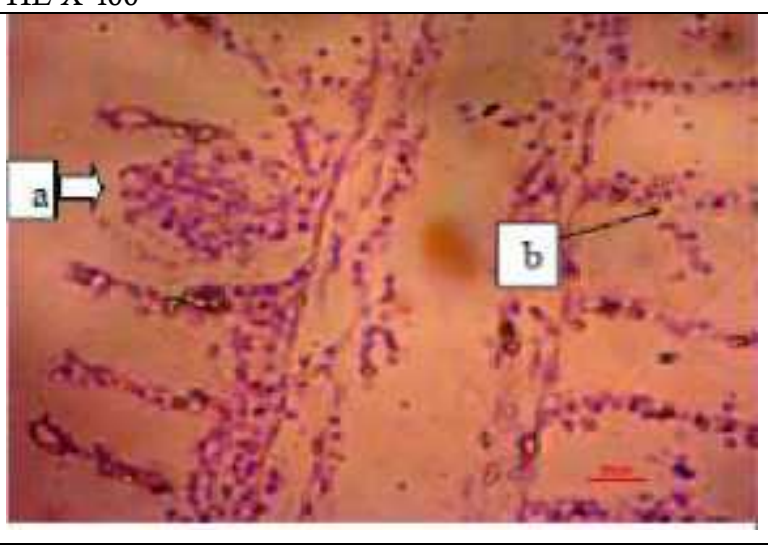

Gambar 5. Penampang membujur lamella sekunder ikan nila dari kolam bekas Pit Galaksi (umur 15 tahun). Terlihat sel-sel epitelium filamen mengalami proliferasi yang menyebabkan adanya fusi antara lamella terdekat (a) dan struktur lamella sekunder mengalami penghancuran (b). HE X 400

\section{PEMBAHASAN}

Kandungan $\mathrm{Pb}$ terbesar terdapat pada daging ikan nila dari kolam Goldstar (10 tahun) yaitu rata-rata sebesar 5,40 mg/Kg, diikuti dari kolam Galaxy Bendang(15 tahun) sebesar 3,35 mg/Kg dan terendah dari kolam Pit Senong(5 tahun) yaitu sebesar 2,92 $\mathrm{mg} / \mathrm{Kg}$. Nilai ini melebihi ambang batas cemaran logam berat pada ikan dan produk perikanan dalam keputusan BPOM No 5 tahun 2018 sebesar 0.20 $\mathrm{mg} / \mathrm{Kg}$ berat bahan. Semua nilai kandungan $\mathrm{Pb}$ lebih tinggi dibandingkan di dalam kolam penelitian (ratarata $<0,003 \mathrm{mg} / \mathrm{L}$ ). Kondisi ini berarti kandungan $\mathrm{Pb}$ di dalam daging ikan terjadi magnifikasi ribuan kali dibandingkan di perairan kolam. Tingginya kadar logam $\mathrm{Pb}$ pada daging ikan Nila dibandingkan dengan pada badan perairan dimungkinkan karena ikan mengabsorpsi timbal yang ada di dasar perairan maupun dari lingkungan air serta plankton yang telah tercemar $\mathrm{Pb}$.

Logam $\mathrm{Pb}$ ini merupakan logam nonesensial yang keberadaannya dalam tubuh makhluk hidup dapat dikatakan tidak diharapkan. Keberadaan logam $\mathrm{Pb}$ dalam tubuh seringkali menggantikan logam esensial dalam aktivitas kerja enzim dan bersifat menghambat kerja enzim (Palar 2008).

Kandungan ion logam Cd terbesar pada ikan nila yang berasal dari kolam Goldstar yaitu rata-rata sebesar 0,03 mg/Kg, Pit Galaxy Bendang dan Pit Senong rata-rata sebesar $0,02 \mathrm{mg} / \mathrm{kg}$. Nilai rata-rata kandungan ion logam $\mathrm{Cd}$ ini masih berada di bawah nilai ambang batas pencemar berdasarkan Keputusan BPOM No 5 tahun 2018 yakni sebesar $0,1 \mathrm{mg} / \mathrm{Kg}$ berat bahan.

Kandungan total ion logam Fe tertinggi terdapat pada Ikan Nila dari kolam Galaxy Bendang sebesar $144,92 \mathrm{mg} / \mathrm{kg}$, sementara itu dari Pit Goldstar rata-rata sebesar 143,67 mg/kg dan dari Pit Senong rata-rata 
sebesar 83,64 mg/ kg.Hasil ini menunjukkan kandungan total ion $\mathrm{Fe}$ berada jauh di atas standar batas aman adanya kontaminan $\mathrm{Fe}$ dalam pangan berdasarkan FAO/WHO (2011) sebesar 0,8 $\mathrm{mg} / \mathrm{kg}$.Hasil penelitian ini menunjukkan bahwa kandungan logam esensial (Fe) di dalam sampel ikan nila lebih tinggi konsentrasinya dibandingkan kandungan logam non esensial ( $\mathrm{Cd}$ dan $\mathrm{Pb})$.

Kandungan ion logam $\mathrm{Pb}$ terbesar terdapat pada daging ikan nila dari kolam Goldstar (10 tahun) yaitu rata-rata sebesar $5,40 \mathrm{mg} / \mathrm{Kg}$, diikuti dari kolam Galaxy Bendang(15 tahun) sebesar 3,35 mg/ $\mathrm{Kg}$ dan terendah adalah dari kolam Pit Senong(5 tahun) yaitu sebesar 2,92 mg/ kg. Nilai ini melebihi ambang batas cemaran logam berat pada ikan dan produk perikanan dalam keputusan BPOM No 5 tahun 2018 sebesar 0.20 $\mathrm{mg} / \mathrm{Kg}$ berat basah.

Kandungan ion logam Cd pada daging tertinggi terdapat dari kolam Goldstar yaitu rata-rata sebesar 0,03 mg/Kg, Ikan Nila dari Pit Galaxy Bendang dan Pit Senong rata-rata sebesar Cd 0,02 mg/ kg. Secara keseluruhan, nilai rata-rata kandungan ion logam $\mathrm{Cd}$ pada daging dari ketiga kolam tersebut masih dibawah batas standar mutu yang ditetapkan Keputusan BPOM No 5 tahun 2018 tentang batas cemaran logam berat dalam ikan dan produk perikanan yaitu 0,1 mg/Kg.Namun demikian,keberadaan logam Cd dalam konsentrasi kecil dapat menyebabkan efek merugikan karena logam ini memblokir gugus sulfhidril di dalam enzim dan bersaing untuk lokasi pengikatan fungsi normal enzim. Paparan logam berat ini dalam jangka panjang bisa bersifat karsinogenik, memengaruhi sistem saraf pusat dan perifer dan efek mengganggu peredaran darah.

Terdeteksinya logam berat $\mathrm{Pb}, \mathrm{Cd}$ dan $\mathrm{Fe}$ pada ikan yang dipelihara di kolam pasca tambang batubara di kawasan ini menunjukkan bahwa logam diakumulasi dalam daging tanpa menyebabkan kematian ikan tersebut. Logam berat $\mathrm{Cd}$ berada di bawah nilai ambang batas yang diperkenankan, sedangkan $\mathrm{Fe}$ dan $\mathrm{Pb}$ berada di atas ambang batas. Perbedaan ini dihasilkan dari afinitas logam yang berbeda terhadap jaringan daging ikan, tingkat penyerapan, deposisi dan ekskresinya.

Di dalam penelitian ini, tampak bahwa tingkat akumulasi di dalam daging ikan nila yang dipelihara di kolam pasca tambang batubara adalah : $\mathrm{Fe}>\mathrm{Pb}>$ $\mathrm{Cd}$. Tingginya kadar $\mathrm{Fe}$ dan $\mathrm{Pb}$ dalam otot ikan sejalan dengan hasil penelitian Andreji et al.,2006 yang melaporkan bahwa logam berat $\mathrm{Fe}>\mathrm{Zn}>\mathrm{Pb}>\mathrm{Cd}>$ $\mathrm{Hg}>\mathrm{Cu}>\mathrm{Mn}>\mathrm{meHg}>\mathrm{Ni}>\mathrm{Cr}>\mathrm{Co}$. Hasil ini sedikit berbeda dengan eksperimen Hafids, dkk ( 2015) yang melaporkan konsentrasi Fe dan Mn dalam ikan nila yang dipelihara selama satu bulan di kolam pasca tambang, menunjukan bahwa dagingnya mengandung logam berat besi $(\mathrm{Fe})$ dan mangan $(\mathrm{Mn})$, namun masih dibawah ambang baku mutu.

Literatur tentang konsentrasi logam berat pada ikan nila yang dipelihara dalam keramba di kolam bekas tambang batubara yang ada di kawasan bekas tambang batubara masih jarang ditemukan. Menurut Wei et al (2018), logam berat (As, Cd, Cr, Cu, Mn, Ni,
$\mathrm{Pb}$, dan $\mathrm{Zn}$ ) dalam air dan sedimen pada tersebut umumnya berasal dari aktivitas penambangan lokal.

Dari Tabel 2, terlihat bahwa kandungan ion logam berat $\mathrm{Cd}, \mathrm{Fe}$ dan $\mathrm{Pb}$ di perairan dari ketiga kolam tersebut memberikan hasil yang sama yaitu masing-masing kurang $<0,002 \mathrm{mg} / \mathrm{L},<0,003 \mathrm{mg} / \mathrm{L}$ dan $<0,003 \mathrm{mg} / \mathrm{L}$. Kondisi ini menunjukkan masih berada di bawah baku mutu yang telah ditetapkan oleh Perda Provinsi Kalimantan Timur No. 02 tahun 2011 tentang baku mutu pada sumber air berdasarkan kelas II sebesar $0,01 \mathrm{mg} / \mathrm{L}$ untuk $\mathrm{Cd}$ dan $0,03 \mathrm{mg} / \mathrm{L}$ untuk $\mathrm{Pb}$.

Namun, berdasarkan data dalam Tabel 1 dan 2 tampak bahwa konsentrasi logam berat $\mathrm{Fe}, \mathrm{Cd}$ dan $\mathrm{Pb}$ dalam jaringan otot ikan nila yang dipelihara di kolam pasca tambang batubara jauh lebih tinggi di dalam badan perairannya.Logam berat $\mathrm{Pb}$ dan $\mathrm{Cd}$ dalam air umumnya berbentuk ion dan logam. Logam tersebut masuk ke tubuh ikan secara langsung atau tidak langsung( melalui membran insang, kulit, lapisan mukosa, makanan tidak langsung dari organisme lain seperti ikan kecil, invertebrata, dan vegetasi air, yang kemudian diangkut darah ke seluruh tubuh kemudian terakumulasi di dalam beberapa organ, salah satunya daging ikan(Polatmet al, 2015).Namun, akumulasi ini tergantung pada asupan, penyimpanan, dan eliminasi dari tubuh.Hal ini berarti logam yang memiliki serapan tinggi dan eliminasi rendah tingkat dalam jaringan ikan diperkirakan akan terakumulasi ke tingkat yang lebih tinggi [Idriss et al.,2015).

Ikan merupakan bahan pangan yang memiliki gizi yang cukup tinggi dan merupakan sumber protein hewani bagi manusia, karena mengandung asam amino yang dibutuhkan oleh tubuh. Hasil penelitian ini menunjukkan bukti ada bioakumulasi berat logam pada ikan dengan tingkat mengkhawatirkan yang lebih tinggi dari batas FAO/WHO (2011) untuk logam berat Fe dan Keputusan BPOM No 5 tahun 2018 untuk logam berat $\mathrm{Pb}$, karena itu, berpotensi menimbulkan risiko bagi konsumen ikan yang berasal dari kegiatan tersebut.

Biomarker stuktur hstologis insang sebagai indikasi status kesehatan ikan yang dipelihara dalam kolam pasca tambang batu bara,menunjukkan sel-sel epitelium filamen mengalami proliferasi yang menyebabkan adanya fusi lamella terdekat, fusi lamella sekunder, sel-sel epitelium mengalami kongesti (aunerisme lamella) dan terdestruksi Struktur insang mengalami( Gambar 3 s.d 5).Struktur insang nila mirip dengan spesies ikan teleost lainnya (Wilson \& Laurent 2002), terdiri dari dua baris filamen yang muncul secara tegak lurus terhadap lamella. Lamella dilapisi oleh epitel squamous yang tidak berdiferensiasi. Di bawah epithelium itu terdapat darah lamelar yang dipisahkan oleh sel-sel pilaster. Di antara lamella, filamen dilapisi oleh epitel berlapis yang dibentuk oleh beberapa tipe seluler, seperti sel klorida, sel mukosa.

Insang merupakan target untuk toksisitas

logam terlarut, karena merupakan situs utama port de entry untuk masuknya polutan, karena miliki karena permukaan yang sangat luas dengan epitel 
tertipis dan logam bisa menembusnya.Kontak terus menerus dan langsung dengan air yang mengandung polutan, akan menyebabkan destruksi morfologi insang epitelium mampu perubahan kadar ion darah, insang $\mathrm{Na}+/ \mathrm{K}+$ ATPase yang diaktifkan dan aliran ionik(Evans,1987).Di sisi lain, terdestruksinya insang bisa mengganggu fungsi pernapasan dan osmoregulasi, maka dapat mengurangi aktivitas berenang ikan karena kekurangan oksigen,dan akhirnya, tingkat pertumbuhan.Tampaknyaperubahan patologis dalaminsang mungkin merupakan respons adaptif untuk mencegah lebih banyak masuknya logam berat. Hiperplasia dalam insang lamellae dapat menunjukkan bukti atau inisiasi kanker, selain mengganggu sirkulasi darah kapiler dan penghambatan aktivitas pertukaran ion.

Hasil penelitian, menunjukkan bahwa struktur insang ikan nila dari kolam Pit Galaksi (berumur 15 tahun),menunjukkan sel-sel epitelium filamen mengalami proliferasi, fusi lamella sekunder, sel sel epitelium mengalami kongesti(aunerisme lamella). Kondisi ini sejalan dengan hasil penelitian yang dilaporkan Ravanaiah and Murthy (2010) bahwa logam berat menyebabkan terjadinya edema yang ditandai adanya pemisahan epitel dan terangkatnya lamella sekunder, perubahan sel klorida dan sel mukosa, proliferasi kartilago pada lamela primer, inti pyknosis,hiperplasia, atrofi, hipertrofi, nekrosis eritrosit pada Tilapia mossambica.

Hal serupa dilaporkan Lopes and Thomas (2011), bahwa adanya perubahan struktur epitel, vakuolisasi, hiperplasia epitel lamela primer, pengangkatan epitel, dan perubahan dari struktur dan terjadinya aneurisma pada lamella sekunder terkait adanya stresor di dalam air.

Struktur insang mengalami destruksi, diduga adanya ion-ion logam berat seperti ion $\mathrm{Pb} 2+$ di dalam perairan kolam pemeliharaan. Kerusakan tersebut diduga akibat pengikatan lendir terhadap sejumlah sejumlah ion $\mathrm{Pb}$ yang melewati lamella sehingga menghalangi proses pertukaran gas dan ion pada lamella dalam sistem respirasi.Pembengkakan ringan sel insang terjadi akibat masuknya ion logam berat sehingga mengakibatkan terangkatnya epitel pipih lamella sekunder yang menyelubungi lamella sekunder yang berfungsi sebagai mekanisme pertahanan. Terangkatnya epitel pipih lamella sekunder mempermudah ion logam dalam air berdifusi untuk ke dalam aliran darah (Antonio et al., 2007).

Diffusi ion logam berat yang secara terus menerus melalui insang memberikan dampak terhadap jaringan insang, sehingga dapat menimbulkan degradasi sel atau kerusakan jaringan dan akhirnya menyebabkan kematian ikan. Hal ini diduga adanya proses anoxemia, yaitu terhambatnya fungsi pernafasan dari insang. Kerusakan insang yang terkena logam berat mengakibatkan adanya degradasi sel atau bahkan kerusakan jaringan insang.

$\mathrm{Fe}$ adalah logam yang penting sebagai bentuk kofaktor bagi banyak enzim dan juga dibutuhkan dalam aktivitas metabolisme organisme hewan.Namun, jumlahnya yang terlalu banyak juga merugikan hewan dan manusia. Logam berat $\mathrm{Pb}$ dan $\mathrm{Cd}$, dalam konsentrasi rendah bersifat toksis.Sebagai kontaminan lingkungan, $\mathrm{Pb}$ sering berkombinasi dengan Cd. Kedua logam berat ini memiliki efek terhadap kesehatan yang serupa dan oleh karena itu dapat menimbulkan efek aditif (Satarug et al, 2003).

Berdasarkan penelitian ini, tampak bahwa untuk memantau kesehatan ikan dalam kegiatan budidaya, diperlukan biomarker organ tubuh sebagai komplementer penggunaan parameter fisikakimia perairan. Parameter histopatologi insang ikan nila telah menunjukkan manfaatnya sebagai biomarker lingkungan perairan budidaya sebagai media pertumbuhannya. Berdasarkan uraian di atas, menunjukkan bahwa terdapat interaksi di antara logam berat melalui proses rumit, yang bergantung pada faktor biotik dan abiotik eksternal dan internal. Karena itu,cukup sulit untuk mengungkapkan pola integrasinya. Interaksi antara logam biasanya menunjukkan kompetitif atau sinergis tergantung pada asal kimianya logam, organ / jaringan yang dianalisis, paparan relatif konsentrasi, dan durasi paparan logam.Dengan demikian, studi lebih lanjut diperlukan untuk mengkonfirmasi mekanisme interaksi untuk berbagai logam, pengaruh kualitas air, konsentrasi, durasi paparan dan semua faktor-faktor ini tampaknya mempengaruhi proses-proses bioakumulasi dan toksisitas polutan yang ada di dalam kolam pasca tambang batubara.

\section{SIMPULAN}

Kandungan $\mathrm{Pb}$ di dalam daging Ikan Nila dari semua kolam pasca tambang batubara berada di antara 2,92 s/d 4,41 mg/kg, sedangkan $\mathrm{Cd}$ antara 0,02 s/d $0,03 \mathrm{mg} / \mathrm{kg}$. Kandungan logam $\mathrm{Pb}$ berada di atas nilai batas cemaran logam berat yang ditetapkan keputusan BPOM No 5 tahun 2018, sedangkan logam berat Cd masih berada di bawah nilai batas cemaran sebesar $0,10 \mathrm{mg} / \mathrm{kg}$.Kandungan total ion logam Fe berada di antara 83,64 s.d. $144,92 \mathrm{mg} / \mathrm{kg}$ dan ikan dari kolam berumur di atas 10 tahun dan 15 tahun mengandung logam $\mathrm{Fe}$ di atas baku mutu yang ditetapkan FAO/WHO sebesar $100 \mathrm{mg} / \mathrm{kg}$.Struktur histopatologis ikan Nila yang berasal dari semua umur kolam pasca tambang menunjukkan adanya kerusakan ditandai terlepasnya sel-sel epitelium lamela sekunder, hiperplasia,fusi lamella sekunder dan . destruksi struktur lamella sekunder dan filament branchia.

\section{DAFTAR PUSTAKA}

Andreji,J.,Ivan,S.,Peter,M., and Miroslav, .2006. Accumulation of Some Metals in Muscles of Five Fish Species from Lower Nitra River Journal of Environmental Science and Health Part A, 41:2607-2622, 2006 
Authman MMN, Zaki MS, Khallaf EA, Abbas HH.2015. Use of Fish as Bio-indicator of the Effects of Heavy Metals Pollution. J Aquac Res Development 6: 328.

Antonio FF, Jorge V, Ferreira C, Sofia GS, Sandra MM, JoaoC, Pedro M, Antonio FF. 2007. Histopathological changes in liver and gill epithelium of nila tilapia (oreochromis niloticus) exposed to waterbone copper. Pesq Vet Bras 27(3):25-30

El-Sikaily, Saad, Kassem.2016.Metallothionein and Glutathione Content as Biomarkers of Metal Pollution in Mussels and Local Fishermen in Abu Qir Bay, Egypt. J Health Pollution 12: 5060

Evans DH. The fish gill: site of action and model for toxic effects of environmental pollutants. Environ Health Perspect. 1987;71:47-58.

FAO/WHO 2011.Joint FAO/WHO food standards programme codex committee on contaminants in foods, March 2011. p 87.

Hafids R, Pagoray H dan Udayana D. 2015. Kandungan Logam Berat Fe dan Mn pada Ikan yang dibudidayakan di Kolam Pasca Tambang Batubara Kabupaten Kutai Kartanegara Kalimantan Timur. Jurnal Ilmu Perikanan Tropis. Vol. 21. No. 1, Oktober 2015:061-067

Idriss AA, Ahmad AK.2015. Heavy metal concentrations in fishes from Juru River, estimation of the health risk. Bull. Environ. Contam.Toxicol., 94:204-208

Jasim BM.,2017. Impact of Certain Heavy Metals on Histology and Physiology of Fishes: Interpretative Study. Annual Research \& Review in Biology 19(6): 1-21.

Lopes,F,F and Thomaz,A.T.2011. Histopatho logic alterations observed in fish gills as a tool in environmental monitoring. Braz. J. Biol., 2011, vol. 71 , no. 1 , p. $179-188$

Badan Pengawas Obat dan Makanan. 2018.Peraturan Badan Pengawas Obat dan Makanan Nomor 5 Tahun 2018 Tentang Batas Maksimum Batas Maksimum Cemaran Logam Berat dalam Pangan Olahan

Palar, H. 2008. Pencemaran dan Toksikologi Logam Berat. Jakarta : Rineka Cipta.

Perry SF, Laurent P.1993. Environmental effects on fish gill structure and function. In: Rankim JC,Jensen FB,editors.Fish Ecophysiology London,UK:Chapman and Hall, pp.231-264.

Polat F, Akın Ş, Yıldırım A, Dal T.2015. The effects of point pollutants originated heavy metals (lead, copper, iron, and cadmium) on fish living inYeşilirmak River, Turkey. Toxicol. Ind. Health, 1-12. Toxicol Ind Health January 9

Ravanaiah G, Narasimha Murthy CV (2010) Impact of aquaculture and industrial pollutants of Nellore district on the histopathological changes in the gill of fish, Tilapia mossambica. Indian J Comp Anim Phsiol 28:108-114
Roy, S.P. 2010. "Overview of Heavy Metals and Aquatic Environment with Notes on Their Recovery." Ecoscan: An International Quarterly Journal of Environmental Sciences 4: 235-240.

Satarug S, Baker JR, Urbenjapol S, Haswellelkins M, Reilly P.E, Williams D.J, et al. A global perspective on cadmium pollution and toxicity in non-occupationally exposed population. Toxicol. Lett. 2003; 137(1), 65-83.

Sorensen, EM. 1991. Metal Poisoning in Fish. Boca Raton, FL: CRC.

Suntoro SH.1983. Metode Pewarnaan, Histologi dan Histokimia. Bhratara Karya Aksara. Jakarta.

Valavanidis A, Vlahogianni T, Dassenakis M, and Scoullos M. 2006. "Molecular Biomarkers of Oxidative Stress in Aquatic Organisms in Relation to Toxic EnvironmentalPollutants."Ecotoxicology and Environmental Safety 64: 178-189.

Wahyuni H,Sasongko S.B, Sasongko DP.2013.Kandungan Logam Berat pada Air, Sedimen dan Plankton di Daerah Penambangan Masyarakat Desa Batu Belubang Kabupaten Bangka Tengah.Prosiding Seminar Nasional Pengelolaan Sumberdaya Alam dan Lingkungan: 489-494

Wei, W., Rui, M., Ziyong,S, Aiguo., Z, Jianwei

B., Xiang, L and Yunde,L.,2018. Effects of Mining Activities on the Release of Heavy Metals (HMs) in a Typical Mountain Headwater Region, the Qinghai-Tibet Plateau in China. Int. J. Environ. Res. Public Health 2018, 15, 1987.

Wood, C.M.,2001. Toxic responses of the gill, In: Target Organ Toxicity in Marine and Freshwater Teleosts Organs, Eds., Schlenk, D. and W.H. Benson vol. 1. Taylor \& Francis, London, 1-89 